\author{
Козак К.Б. \\ кандидат економічних наук, доцент \\ E-mail: kozak-ekaterina@list.ru \\ Маркова Г.Ф. \\ магістрант \\ кафедра менеджменту та логістики \\ Одеська національна академія харчових технологій \\ вул. Канатна, 112, г. Одеса, Україна, 65039 \\ E-mail: anna93markova@gmail.com
}

\title{
ДОСЛІДЖЕННЯ ПРОБЛЕМ УПРАВЛІННЯ ПЕРСОНАЛОМ В ГОТЕЛЬНО-РЕСТОРАННІЙ ГАЛУЗІ
}

\begin{abstract}
В даній статті розглянуті особливості сучасного розвитку економіки і суспільства взагалі, розкрита роль ефрективного управління персоналом як одного $з$ найважливіших факторів розвитку будьякої діяльності. Проаналізовано тенденції розвитку готельно-ресторанного бізнесу та актуальність особливої уваги саме до цієї сфери. Виявлено основні проблеми управління персоналом в сучасних умовах, визначено важливі функції управління.
\end{abstract}

Ключові слова: управління персоналом, готельно-ресторанна галузь, трудові ресурси, проблеми управління персоналом, система мотивації.

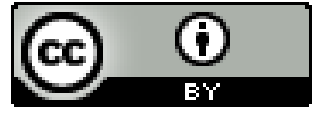

This work is licensed under a Creative Commons Attribution 4.0 International License http://creativecommons.org/licenses/by/4.0/
Постановка проблеми та їі зв'язок 3 важливими науковими та практичними завданнями. Сучасні умови діяльності підприємств пред'являють якісно нові вимоги до менеджерів з персоналу, обумовлюють необхідність більш високої інтенсивності їхньої праці, уміння цінувати час, володіти комплексом організаційних і психологічних якостей, забезпечувати творчий підхід до роботи. У цьому зв'язку особливої актуальності набуває удосконалення якісного змісту діяльності управління персоналом [1].

В даний час індустрія гостинності є однією 3 галузей, яка найбільш динамічно розвивається в світовому господарстві та відіграє величезну роль в економіці держави, оскільки не тільки приносить чималий дохід, але також сприяє створенню нових робочих місць.

Аналіз останніх публікацій по проблемі. Теоретичні аспекти управління розвитком персоналу досліджували ряд зарубіжних і вітчизняних вчених, зокрема: Бісвас П.Ч., Свтушевський В.А., Козак К.Б., Крушельницька О.В., Мельничук Д.П., Савченко В.А. та ін. Однак внаслідок складності й багатоаспектності цієї проблеми в сучасних умовах існують питання, які розглянуті неповністю.

Формулювання цілей дослідження. Метою статті є дослідження проблем управління персоналом в готельно-ресторанній галузі.
Виклад основних результатів та їх обгрунтування. Орієнтація економіки на ринкові відносини докорінно змінює підходи до рішення багатьох економічних проблем i, насамперед тих, котрі пов'язані 3 людиною. Тому зрозуміла та увага, що приділяється концепції управління, у центрі якої знаходиться людина. Відповідно до неї всі системи управління націлені на більш повне використання здібностей працівника в процесі виробництва та надання послуг, що є основою ефективної діяльності підприємства. Дійсно, використання речового фактора виробництва залежить від рівня розвитку працівника, сукупності його професійних знань, умінь, навичок, здібностей і мотивів до праці [3].

Практичне застосування управління людськими ресурсами підприємства вимагає врахування ряду зовнішніх факторів і чіткого розуміння недоліків, властивих традиційній системі.

Практична значимість управління персоналом полягає у наступному:

- ідеальне конструювання практики кадрового управління, розробка теорії, стратегії, техніки, способів і засобів управління персоналом;

- раціоналізація та глибоке критичне осмислення практичного управління людьми і його орієнтація на вимоги економічної і соціальної ефективносTi; 
- спонукання керівників до зміни моделей, техніки, стилю, способів і засобів керівництва робітниками на основі альтернатив, запропонованих наукою [2].

Отже, робота будь-якого підприємства неминуче пов'язана з необхідністю комплектування штату. Добір нових працівників не тільки забезпечує режим нормального функціонування підприємства, але й закладає фундамент майбутнього успіху. Від того, наскільки ефективно поставлена робота з добору персоналу, у значній мірі залежить якість людських ресурсів, їхній внесок у досягнення цілей підприємства та якість виробленої продукції чи наданих послуг.

У сучасних умовах пошук та добір персоналу $\epsilon$ найважливішою складовою кадрової політики, реалізованої підприємством, і одним із ключових елементів системи управління персоналом, тісно пов'яза ним практично з всіма основними напрямками роботи в цій сфері.

Так, підприємству у сфері готельноресторанної галузі слід інтенсифікувати власні зусилля у таких напрямках роботи з персоналом:

- кадрове планування;

- аналіз роботи, нормування праці й оцінка виконання;

- система стимулювання;

- організаційна культура;

- система заходів для адаптації нових працівників до роботи на підприємстві та до трудового колективу;

- навчання.

У ринкових відносинах між процесами виробництва продукції і використанням трудових ресурсів підприємства існує така ж рівновага, як між попитом та пропозицією, витратами і результатами, доходами підприємства i рівнем життя працівників. Будь-яка діяльність персоналу підприємства повною мірою повинна відповідати вимогам існуючого механізму ринкових трудових відносин у сучасному виробництві і забезпечувати високий ріст продуктивності праці[9].

Важливими є такі сучасні функції управління персоналом у готельно-ресторанній галузі:

- планування якісного і кількісного складу працівників;

- інформаційне забезпечення системи управління персоналом;

- соціально-психологічна діагностика людських ресурсів, аналіз і регулювання взаємовідносин у колективі;

- управління виробничими i соціальними конфліктами, формування стабільного трудового колективу;

- планування ділової кар’єри працівників;

- професійна і соціально-психологічна адаптація нових працівників;

- аналіз і оцінка кадрового потенціалу;

- формування кадрового резерву;

- маркетинг персоналу.

Ефективне функціонування підприємств готельно-ресторанної галузі неможливе, якщо структурні підрозділи дублюють функції один одного. Тому на кожному підприємстві повинен існувати чіткий поділ праці між окремими працівниками та підрозділами [11]. Від того наскільки ефективно проводиться політика управління персоналом залежить діяльність підприємства. Персонал грає важливу роль в успішному розвитку підприємства, тому необхідно чітко підходити до вибору методів управління персоналом. Від вибору тих чи інших методів управління персоналом залежить якість організації праці на підприємстві, яка приводить до укріплення зв'язків в трудовому колективі, що є важливим елементом ефективного управління персоналом [6].

Без людей немає підприємства. Без потрібних людей жодне підприємство не зможе досягти своїх цілей і вижити у конкурентній боротьбі. Безсумнівно, що трудові ресурси, які належать до соціальноекономічної категорії, є одним $з$ найважливіших аспектів теорії і практики управління на підприємстві будь-якої галузі, у тому числі і у готельноресторанній. Готельне господарство є головним фактором і основною складовою туристичної інфраструктури країни та відіграє провідну роль у презентації вітчизняного туристичного продукту на світовому ринку туристичних послуг. Ця сфера в комплексі туристичних послуг світового господарства розвивається швидкими темпами і в перспективі, згідно прогнозів відомих профільних експертів, може стати найбільш важливим сектором туристичної діяльності.

Сфера гостинності охоплює різні групи підприємств, включаючи готелі, мотелі, гостьові будинки, ресторани, кафе, магазини туристських товарів, парки відпочинку, інші сфери, пов'язані з туризмом і відпочинком, які надають соціальні та персональні послуги. Головним призначенням індустрії гостинності $\epsilon$ створення та забезпечення комфортабельного відпочинку шляхом надання послуг туристам, які відвідують країну чи місто в різних цілях.

Загальна кількість зайнятих працівників на суб'єктах господарювання у 2014 році у галузі тимчасового розміщування й організації харчування 213,2 тис. осіб, у тому числі на підприємствах - 101,5 тис. осіб, у фізичних осіб-підприємців - 111,7 тис. осіб [10].

Кількість суб'єктів господарювання тимчасового розміщування й організації харчування у 2014 році складає 57553 одиниці, у тому числі підприємств - 7885 одиниць, фізичних осіб - 49668 одиниць. 
Кількість підприємств тимчасового розміщування і організації харчування за їх розмірами у 2014 році - 7885 одиниць, з яких великих і середніх 292 одиниць, малих - 7593 одиниці [10].

Кількість підприємств готельного типу, кількість номерів та житлової площі всіх номерів має те- нденцію зростання, що свідчить про актуальність розвитку готельно-ресторанної галузі, а збільшення цих показників свідчить про необхідність зростання потреби в трудових ресурсах ( рис.1, 2) [10].

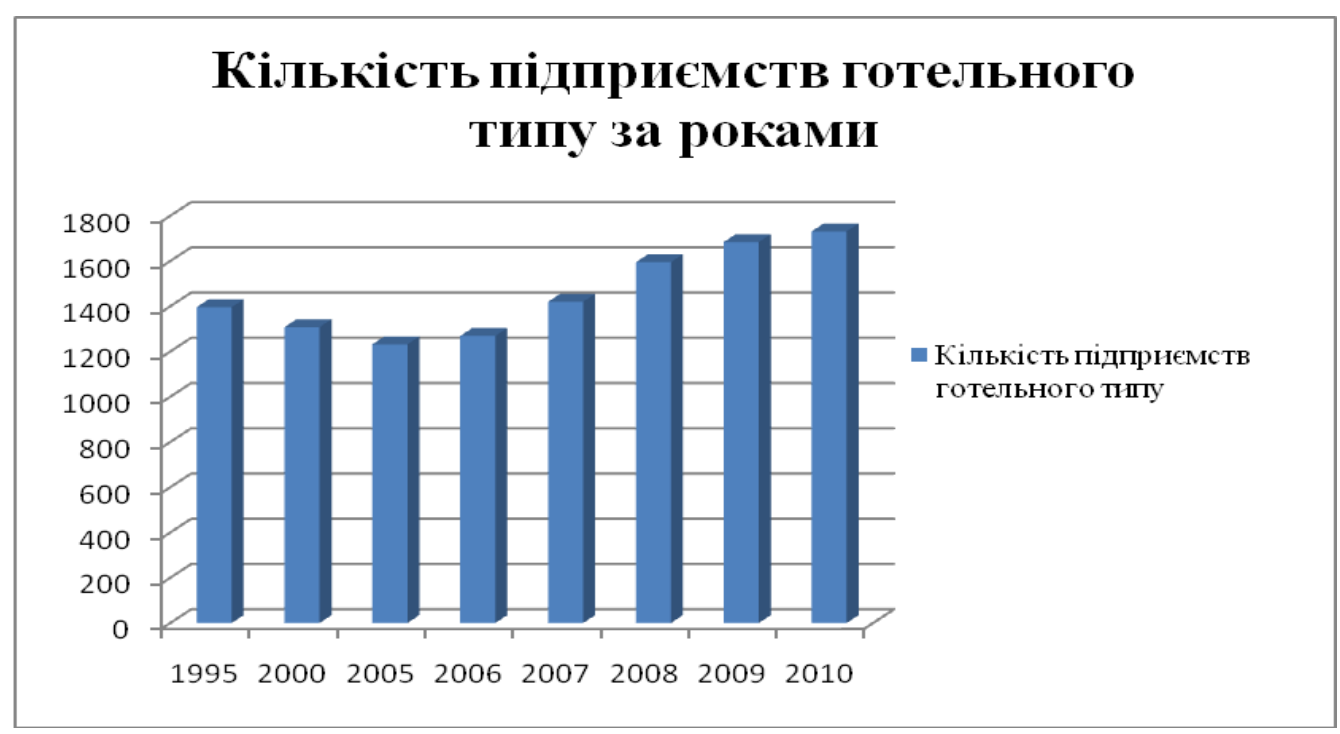

Рис. 1. Кількість підпримств готельного типу за роками [10]

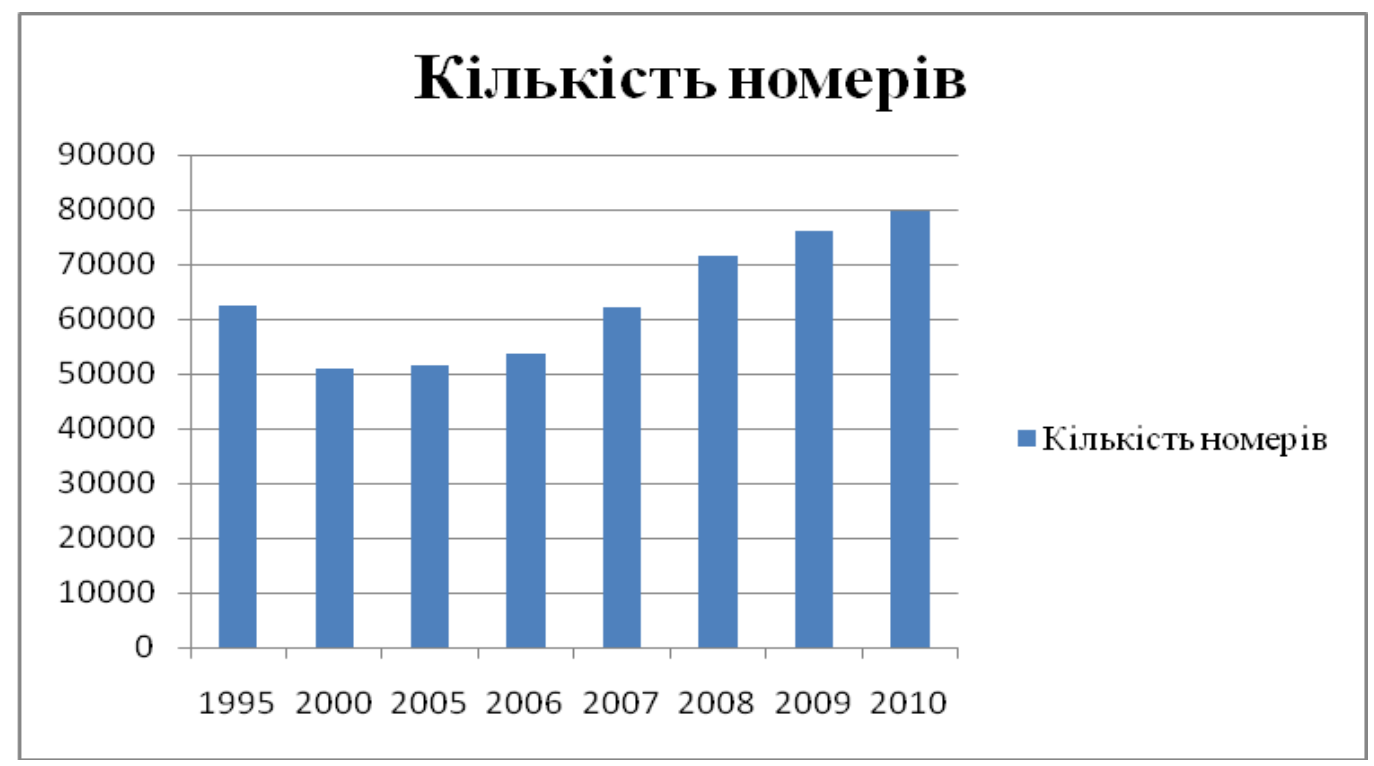

Рис.2. Кількість номерів підприсмств готельного типу [10]

Специфіка готельно-ресторанної галузі полягає в тому, що даний вид діяльності являє собою, насамперед, продаж послуг, якість надання яких залежить від виконавця, тобто від персоналу готелю. Аналіз сучасного стану людських ресурсів підприємств сфери готельного бізнесу показує, що проблема оцінки, раціонального та ефективного їх використан- ня стає першорядною.

Для готельно-ресторанної галузі трудові ресурси мають величезне значення, оскільки запропоновані готелями послуги відносяться до явищ нематеріального характеру. Добробут підприємства багато в чому залежить від професіоналізму його персоналу. Створення високоефективного готельного господарс- 
тва відіграє важливе значення, як один з пріоритетних напрямів удосконалення економіки України.

Актуальною проблемою $є$ впровадження у систему управління вітчизняними готельними підприємствами сучасних ефективних моделей управління, що відповідають світовим стандартам, які обумовлені необхідністю надання високоякісних послуг, зниження витрат, координації персоналу, проведення маркетингових досліджень ринку готельних послуг [4].

Глибокі зміни в структурі і якості робочої сили, у змісті праці, вичерпання резервів зростання ефективності праці за рахунок фізичних можливостей потребують нетрадиційних підходів щодо стимулювання мотивації праці. При цьому завдання полягає в приведенні в дію можливостей працівника, пов'язаних 3 його майстерністю, освітою та фаховою підготовкою, розвитком трудового потенціалу, прагненням до творчості й самореалізації [11].

Отже, недосконале управління персоналом готелю відбивається на прибутку підприємства практично відразу: результати численних досліджень показали, що між лояльністю працівників та лояльністю клієнтів готелю існує кореляція. Тому система мотивації на підприємствах готельно-ресторанної галузі має уникати:

- «каральних» прийомів мотивації, що сприяють збереженню найбільш креативних, активних i компетентних працівників;

- нестабільності (мотивація повинна носити системний характер);

- ігнорування очікувань та інтересів працівників;

- невідповідності між системою мотивації i загальною стратегією підприємства.

Разом 3 тим, в Україні у готельноресторанній галузі склалася ситуація, коли управлінню персоналом не приділяється достатньої уваги та виявлені наступні основні проблеми:

- недосконала технологія розробки і прийняття кадрових рішень;

- у більшості випадків відсутня орієнтація на досягнення соціальної ефективності в управлінні персоналом;

- погано впроваджуються методи набору, оцінки, розміщення і навчання кадрів, що знижує економічну та соціальну ефективність управління персоналом;

- високий рівень плинності кадрів, який заважає плануванню роботи колективу.

Всі перелічені вище проблеми впливають на використання трудового ресурсу, адже головною проблемою є все ж таки матеріальна мотивація, тому що гроші і соціальний пакет можуть залучити і утримувати, але не можуть викликати повної віддачі, зробити цілі компанії своїми власними. Незалежно від професії й організації, людина схильна привносити в свою діяльність своє «Я», індивідуальність і прагнути таким чином висловити або реалізувати їі через процес роботи, досягнутий результат, свою роль в колективі.

Так, широко розповсюдженим засобом впливу на працівника, на трудові відносини, що складаються, є мотивація праці, що передбачає:

- систему винагороди, матеріального і морального заохочення;

- збагачення змісту праці, підвищення інтересу до роботи;

- розвиток персоналу, надання можливості професійно-кваліфікаційного просування, планування

кар'єри;

- активне залучення працівників до управління трудовими процесами, участь у прибутках i акціонерному капіталі готелю тощо;

- поліпшення соціально-психологічного клімату в готелі завдяки зміні стилю управління, умов наймання і роботи, заохоченню індивідуальної і групової ініціативи, творчості і саморозвитку[8].

Таким чином, можливо припустити, що умовами для ефективного управління трудовими ресурсами у готельно-ресторанній галузі є: індивідуальне планування кар'єри, підготовка та перепідготовка персоналу, стимулювання професійного росту; гнучкі системи організації робіт; принципи врахування індивідуального вкладу працівників та рівня їх професійної компетенції в системі оплати праці; високий рівень участі працівників у розробці та прийнятті управлінських рішень; практика делегування повноважень підлеглим; задоволеність результатами праці; система інформування працівників, корпоративні засоби інформації; рівень корпоративної культури, рівень дисципліни; система атестації персоналу, наявність кадрового резерву; мета функціонування підприємства, способи ії досягнення, філософія діяльності, суспільне значення [5, 7].

В даний час управління персоналом є необхідним компонентом управлінського, економічного та інших напрямків підготовки. Навчання менеджерів основним принципам і методам управління персоналом, у тому числі в готельно-ресторанній галузі, буде сприяти формуванню в них розуміння важливості ефективності і науково обгрунтованої роботи з людьми, зростанню престижу кадрових служб і підвищенню ефективності використання трудового ресурсу.

Висновки та перспективи подальших досліджень. Із набуттям Україною не формального, а реального суверенітету першорядного значення набуває впровадження передових організаційноуправлінських технологій в таку важливу іiі соціально-економічну сферу господарства як готельноресторанна галузь. Наша країна перейшла до ринко- 
вих відносин у час, коли на міжнародному ринку сталися суттєві зміни в туристичній галузі, важливою складовою якої є готельно-ресторанний сервіс. Актуальність завдань щодо формування й впровадження новітніх організаційно-управлінських засад зростає 3 поглибленням процесів входження України до високо розвиненого соціально-економічного, культурного й правового поля Європи й світу, в цілому вже опанованого досконало організованими, нормативно врегульованими та взаємопов'язаними туристичним системами.

Отже, щоб економіка управління персоналом готелю забезпечувала найкращі результати, слід створити чітку систему роботи 3 кадрами, що охоплює область не тільки повсякденних завдань, яки ви рішуються за допомогою адміністративного втручання, але й стратегічних питань.

Так, міжорганізаційні зв'язки дозволяють об'єднати інтелектуальні ресурси підприємств з метою впровадження різного роду інновацій у їхню діяльність. На внутрішньоорганізаційному рівні керівники і менеджери повинні усвідомити недоліки традиційної концепції управління персоналом і необхідність формування нової кадрової політики, корпоративної філософії керівництва.
Це буде сприяти досягненню соціального партнерства в колективі, узгодженню економічних і соціальних інтересів окремих працівників і робочих груп.

На основі дослідження практичних та вивчення теоретичних основ управління персоналом підприємств готельно-ресторанної галузі можемо зробити наступні висновки, щодо наявності певних проблем:

- підприємства сфери ГРС постійно відчувають гостру потребу в персоналі високої кваліфікації та мотивації;

- система мотивації підприємства повинна бути вдосконалена і адаптована під конкретні умови роботи;

- виявлена гостра необхідність у розробці нового та вдосконаленні вже існуючого ефективного механізму підбору та відбору персоналу.

Виходячи $з$ виявлених проблем щодо управління персоналом в подальших розробках будуть запропоновані можливі методи їх розв'язання для підвищення ефективності діяльності підприємства готельно-ресторанної галузі країни.

\section{Література}

1. Балабанова Л.В. Управління персоналом: підручник / Л.В. Балабанова, О.В.Сардак. - К.: Центр учбової літератури, 2011. -468 с.

2. Брагина 3.В. Управление персоналом: учебное пособие для вузов / Брагина 3.В., Дудяшова В.П., Каверина 3.Т. - М.: КноРус, 2010. - 125 с.

3. Братченко В.Ф. Управління персоналом організації в сучасних умовах // Персонал. - 2006. - № 3. C. 25 .

4. Готельно-ресторанний бізнес, як основна складова туристичної індустрії. [Електронний ресурс]. Режим доступу: http://libr.rv.ua/ua/virt/78/

5. Економіка підприємства: підручник / За ред. А.В.Шегди. - К.: Знання, 2006. - 614 с.

6. Кравчено Т.С. Аналіз концепцій кадрового менеджменту // Персонал. - 2005. - №7. - С.13-21.

7. Козак К.Б. Управління розвитком трудового потенціалу підприємства: дис. канд. екон. наук : 08.00.04 - економіка та управління підприємствами (за видами економічної діяльності) / К.Б.Козак. - Херсон, 2011. $-245 \mathrm{c}$.

8. Роглєв Х.Й. Основи готельного менеджменту [Електронний ресурс]: навчальний посібник / Х.Й. Роглєв. - К.: Кондор, 2005. - 408 с. - Режим доступу: http://tourlib.net/books_ukr/roglev.htm

9. Шапиро С.А. Основы управления персоналом в современных организациях. Экспресс-курс: учебное пособие / С.А. Шапиро, О.В. Шатаева. - М.: Институт международных государственно - гуманитарных связей, 2008. -99 c.

10. Державна служба статистики України [Електронний ресурс]. - Режим доступу: http://www.ukrstat.gov.ua/

11. Нечаюк Л.І. Готельно-ресторанний бізнес: менеджмент [Електронний ресурс] : навчальний посібник / Л.І.Нечаюк, Н.О. Телеш. - К.: Центр навчальної літератури, 2003. - 348 с. - Режим доступу: http://tourlib.net/books_ukr/nechauk.htm 


\author{
Козак Е.Б. \\ кандидат экономических наук, доцент \\ E-mail: kozak-ekaterina@list.ru \\ Маркова А.Ф. \\ магистрант \\ кафедра менеджмента и логистики \\ Одесская национальная академия пищевых технологий \\ ул. Канатная, 112, г. Одесса, Украина, 65039 \\ E-mail: anna93markova@gmail.com
}

\title{
ИССЛЕДОВАНИЕ ПРОБЛЕМ УПРАВЛЕНИЯ ПЕРСОНАЛОМ В ГОСТИНИЧНО-РЕСТОРАННОЙ ОТРАСЛИ
}

\begin{abstract}
В данной статье представлены результаты исследования проблем управления персоналом в гостинично-ресторанной отрасли, а также важность сферы гостеприимства для туристической инфраструктуры страны.

Рассмотрены актуальность решения проблем управления персоналом в современных условиях развития предприятий. Выделены составляющие практической значимости управления персоналом, такие как: идеальное конструирование практики кадрового управления, разработка теории, стратегии, техники, способов и средств управления персоналом, рационализация практического управления людьми, ориентация на требования экономической эффективности, побуждение руководителей к выбору моделей управления из ряда современных альтернатив.

Определено, что в современных условиях поиск и подбор персонала является важнейшей составляющей кадровой политики предприятия и ключевым элементом системы управления персоналом.

Выделены направления работы с персоналом, в которых следует интенсифицировать усилия предприятию: кадровое планирование, анализ работы, нормирование труда и оценка исполнения, система стимулирования, организационная культура, система мер по адаптации новых работников к работе на предприятии, обучение.

Рассмотрены важные функции управления персоналом, специфика гостинично-ресторанной отрасли, необходимость внедрения современных эфффективных моделей управления, связь системы мотивации и работы персонала.

Выделены составляющие системы мотивации труда и условия для эффективного управления трудовыми ресурсами, а также существующие основные проблемы управления персоналом: несовершенная технология разработки и принятия кадровых решений, отсутствие ориентации на достижение эффрективности, недостаточное внедрение методов набора, оценки и обучения кадров.

Сделаны выводы о необходимости создания четкой системы работы с сотрудниками, осознание недостатков традиционной отечественной концепции управления персоналом, формирование новой кадровой политики, корпоративной философии руководства.

Ключевые слова: управление персоналом, гостинично-ресторанная отрасль, трудовые ресурсы, проблемы управления персоналом, система мотивации.
\end{abstract}

\section{Kozak K.B.}

Ph.D. in Economics, Associate Professor

E-mail:kozak-ekaterina@list.ru

Markova H.F.

undergraduate

Department of Management and Logistics

Odessa National Academy of Food Technologies

Kanatna str., 112 Odessa, Ukraine, 65039

E-mail: anna93markova@gmail.com

\section{RESEARCH OF PROBLEMS OF HUMAN RESOURCE MANAGEMENT IN HOTEL AND RESTRAUNT BRANCH}

This article presents the results of research into the problems of a human resource management in the hotel and restaurant industry and the importance of hospitality areas for tourism infrastructure in Ukraine. 
It is dealt with the relevance of solving the problems of the human resource management in the modern conditions of development of enterprises. The components of a practical importance of HR management are: ideal designing of a practice of personnel administration; development of the theory, strategy , equipment, ways and control facilities of the personnel; rationalization of a practical management of people; orientation to requirements of the economic efficiency; motivation of the heads to make a choice of models of management from a number of modern alternatives.

It is determined that in a modern conditions, search and staff recruitment are the most important part of the human resource policies of the enterprise and are the key elements of a human resource management system.

The areas of work with the personnel in which the enterprise should intensify its efforts are : personnel planning, the analysis of work, rationing of work and an assessment of execution, system of stimulation, organizational culture, system of measures for adaptation of new workers to work in the enterprise, training.

It is investigated the important functions of the human resource management, specifics of hotel and restaurant branch, necessity of introduction of a modern effective models of management, communication of a system of motivation and work of the personnel.

There are emphasized the main existing problems of the human resource management. The first one is the imperfect technology of development and adoption of personnel decisions. The second one is an absent orientation to achievement of efficiency. Third - methods of a set, an assessment and personnel training are badly introduced.

Attention is drawn to the components of the work motivation system and to the conditions for effective management of the workforce.

Conclusions and some measures are drawn on the necessity of the creation of an accurate system of work with workers, on the understanding of defects of the traditional native concept of the human resource management, on formation of a new personnel policy and a corporate philosophy of the management.

Keywords: human resource management, hotel and restaurant branch, problems of a human resource management, workforce, work motivation system

\section{References}

1. Balabanova, L., \& Sardak, O. (2011). Upravlinnia personalom: Pidruchnyk (p. 468). Kiyv: Tsentr uchbovoi literatury.

2. Brahyna, Z., Dudiashova, V., \& Kaveryna, Z. (2010). Upravlenye personalom: Uchebnoe posobye dlia vuzov (p. 125). Moskva: KnoRus.

3. Bratchenko, V. (2006). Upravlinnia personalom orhanizatsii v suchasnykh umovakh. Personal, (3), 25.

4. Hotelno-restorannyi biznes, yak osnovna skladova turystychnoi industrii. (2014, December 12). Retrieved September 2, 2015, from http://libr.rv.ua/ua/virt/78/

5. Shehdy, A. (2006). Ekonomika pidpryiemstva (p. 614). Kiyv: Znannia.

6. Kravcheno, T. (2005). Analiz okontseptsii kadrovoho menedzhmentu. (7), 13-21.

7. Kozak, K. (2011). Upravlinnia rozvytkom trudovoho potentsialu pidpryiemstva (p. 245). Kherson.

8. Rohliev, K. (2005, August 22). Osnovy hotelnoho menedzhmentu. Retrieved September 10, 2015, from http://tourlib.net/books_ukr/roglev.htm

9. Shapyro, S., \& Shataeva, O. (2008). Osnovu upravlenyia personalom v sovremennukh orhanyzatsyiakh (p. 99). Moskva: Ynstytut mezhdunarodnukh hosudarstvenno - humanytarnukh sviazei.

10. Derzhavna sluzhba statystyky Ukrainy. (2014, November 15). Retrieved September 3, 2015, from http://www.ukrstat.gov.ua/

11. Nechaiuk, L., \& Telesh, N. (2003). Hotelno-restorannyi biznes: Menedzhment (p. 348). Kiyv: Tsentr navchalnoi literatury

Received 21 September 2015

Approved 6 October 2015

Available in Internet 26.12.2015 